\title{
Surface chemical and color characterization of juvenile tectona grandis wood subjected to steam-drying treatments
}

Article in Surface Review and Letters · September 2015

DOI: 10.1142/S0218625X15500912

CITATION

1

5 authors, including:

\section{Alexander Berrocal}

Costa Rican Institute of Technology (ITCR)

29 PUBLICATIONS 132 CITATIONS

SEE PROFILE

M, Rodríguez-Solís

Costa Rican Institute of Technology (ITCR)

9 PUBLICATIONS 2 CITATIONS

SEE PROFILE
READS

85

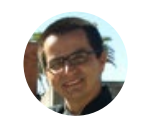

Roger Moya Roque

Costa Rican Institute of Technology (ITCR)

176 PUBLICATIONS 853 CITATIONS

SEE PROFILE

Ricardo Starbird

Costa Rican Institute of Technology (ITCR)

18 PUBLICATIONS 34 CITATIONS

SEE PROFILE

Some of the authors of this publication are also working on these related projects: 


\title{
SURFACE CHEMICAL AND COLOR CHARACTERIZATION OF JUVENILE TECTONA GRANDIS WOOD SUBJECTED TO STEAM-DRYING TREATMENTS
}

\author{
ALEXANDER BERROCAL*, RÓGER MOYA ${ }^{\dagger}$ \\ and MARÍA RODRIGUEZ-SOLIS* \\ Escuela de Ingeniería Forestal \\ Instituto Tecnológico de Costa Rica \\ Apartado 159-7050, Cartago, Costa Rica \\ *aberrocal@itcr.ac.cr \\ ${ }^{\dagger}$ rmoya@itcr.ac.cr \\ \$maria.rodriguez@itcr.ac.cr \\ RICARDO STARBIRD \\ Escuela de Química, Instituto Tecnológico de Costa Rica \\ Apartado 159-7050, Cartago, Costa Rica \\ rstarbird@itcr.ac.cr \\ FREDDY MUÑOZ \\ Escuela de Ingeniería Forestal \\ Instituto Tecnológico de Costa Rica \\ Apartado 159-7050, Cartago, Costa Rica \\ fmunoz@itcr.ac.cr
}

Received 4 June 2015

Revised 22 September 2015

Accepted 23 September 2015

Published

\begin{abstract}
The color of Tectona grandis wood is an attribute that favors its commercialization, however, wood color from fast-growth plantation trees is clear and lacks uniformity. The aim of this work is to characterize steamed teak wood by means of the Fourier transform infrared spectroscopy (FTIR) and $L^{*} a^{*} b^{*}$ color systems. Two moisture conditions (green and 50\%) and two grain patterns (flat and quarter) of boards were analyzed through the application of different steaming times $(0,3,6,9$, 12,15 and $18 \mathrm{~h}$ ). The FTIR results showed that the bands at $1158,1231,1373$ and $1419 \mathrm{~cm}^{-1}$ did not show any change with steaming, whereas the bands at 1053, 1108, 1453, 1506, 1536, 1558, 1595, $1652,1683,1700$ and $1733 \mathrm{~cm}^{-1}$ presented a decrease in the intensity with the steaming time. The band at $1318 \mathrm{~cm}^{-1}$ was the only one that increased. Lightness $\left(L^{*}\right)$ was the most affected parameter, followed by yellowness $\left(b^{*}\right)$, while redness $\left(a^{*}\right)$ showed the smallest change. Surface color change $\left(\Delta E^{*}\right)$ presented the lowest value between $3 \mathrm{~h}$ and $6 \mathrm{~h}$ of steam-drying in the boards with flat grain, whereas for boards with quarter grain, the smallest $\Delta E^{*}$ value was obtained after $18 \mathrm{~h}$ of steaming.

Keywords: Wood treatment; steam-drying treatment; surface analysis; tropical wood; color uniformity.
\end{abstract}

†Corresponding author. 


\section{Introduction}

Tectona grandis L.f. has been largely planted in many tropical regions, including Latin America, Asia, Africa and Oceania, covering approximately 6 million ha. ${ }^{1}$ Thanks to its physical, mechanical and aesthetical properties, the wood of this tropical species has become one of the most important in international markets. $^{2}$

Additionally, teak wood color is considered a major attribute regarding commercialization. ${ }^{3}$ Thulasidas et $a ._{.}{ }^{4}$ indicated that teak wood is a premier hardwood valued for the attractiveness of its golden yellow or brown color.

Teak color has been widely studied in the past few years. $^{2}$ The color of the wood from trees grown in plantations is lighter than the color of the wood from natural forests. ${ }^{5,6}$ For this reason, the price of the wood from trees from short-rotation plantations is lower in the timber market. ${ }^{4}$

In addition to its lighter color, the great variability of the heartwood color of teak wood is another inconvenience. $^{3,7}$ For example, Moya and Berrocal ${ }^{7}$ found approximately $15 \%$ variation in the wood color parameters (lightness $\left(L^{*}\right)$, redness $\left(a^{*}\right)$ and yellowness $\left.\left(b^{*}\right)\right)$. Thulasidas et al. ${ }^{4}$ found a similar variation in wood from homegarden trees. Finally, Moya and Marín ${ }^{5}$ found $31-53 \%$ variation in the color parameters $\left(L^{*}, a^{*}, b^{*}\right)$ in cloned trees.

There are various techniques to homogenize the color of the wood or to try to achieve more uniform darker colors. ${ }^{8}$ Steam-drying treatment has been known for a long time as one of the most effective methods to improve the dimensional stability, decay resistance and durability of wood, while simultaneously darkening the wood color. ${ }^{9}$ In terms of the mechanism for the dark color development, the properties and quantities of major chemicals and extractive compositions in wood are modified during the steam-heat treatment. ${ }^{9}$

Wood color can also be homogenized through drying. However, studies on how to obtain darker teak wood are still unfinished. ${ }^{2}$ For example, in a first attempt, Berrocal and Agüero ${ }^{10}$ applied a system of preservation and coloring in order to homogenize the color of the sapwood and the heartwood. Salas and Moya, ${ }^{11}$ meanwhile, found that lightness diminished while redness and yellowness increased after the process of wood drying with three different methods (air, kiln and solar drying), thus resulting in darker wood.

Other forms of changing the color of teak wood have been implemented which focus on growing trees. They are focused on when the trees are growing. Recently, Moya and Marín ${ }^{5}$ proposed the genetic selection of trees with similar color conditions to that of trees growing in plantation conditions, in order to achieve darker and less variable improved teak wood.

The color change produced by steaming or drying is caused by chemical changes in the wood surface. The Fourier transform infrared spectroscopy (FTIR) has made it possible to perceive those changes. Specifically, changes occurring in the $800-1800 \mathrm{~cm}^{-1}$ band are being studied. ${ }^{12}$ Huang et al. ${ }^{13}$ and Lionetto et $a l .{ }^{14}$ have shown that employing the ratio $\mathrm{I}_{1316} /$ $\mathrm{I}_{1336}$ provides information concerning the process of degradation of the amorphous and crystalline cellulose zones during the steaming. Moreover, changes due to steaming at peaks at 1738, 1596 and $810 \mathrm{~cm}^{-1}$ show alterations in the wood hemicellulose and lignin. ${ }^{12,15}$

Although efforts have been made to standardize the color of teak wood from plantation trees, little research has been conducted as to the changes produced by steaming in combination with drying on the wood of trees from fast-growth plantations. Therefore, the aim of the present study is to establish the changes of color (measured by $L^{*} a^{*} b^{*}$ color systems) as well as the chemical changes (by FTIR measurements) occurring in the wood surface, using various steaming times $(0,3,6,9,12,15$ and $18 \mathrm{~h})$ in flat and quarter pattern boards in two conditions of moisture content (MC): green and 50\%. This work will allow to establish the best conditions regarding steaming time and MC of Tectona grandis with different grain patterns.

\section{Materials and Methods}

\subsection{Provenance of the wood, sampling and moisture condition}

For the present study, 11-year-old trees from a second thinning intervention in a plantation owned by Aserradero S\&Q, located in Rincón de Osa in the province of Puntarenas, Costa Rica ( $8^{\circ} 40^{\prime} 38^{\prime \prime} \mathrm{N}$; $\left.83^{\circ} 29^{\prime} 43^{\prime \prime} \mathrm{W}\right)$, were used. Tectona grandis 11 years old with $3 \times 3 \mathrm{~m}$ spacing (1100 trees $\cdot \mathrm{ha}^{-1}$ ). Stand 


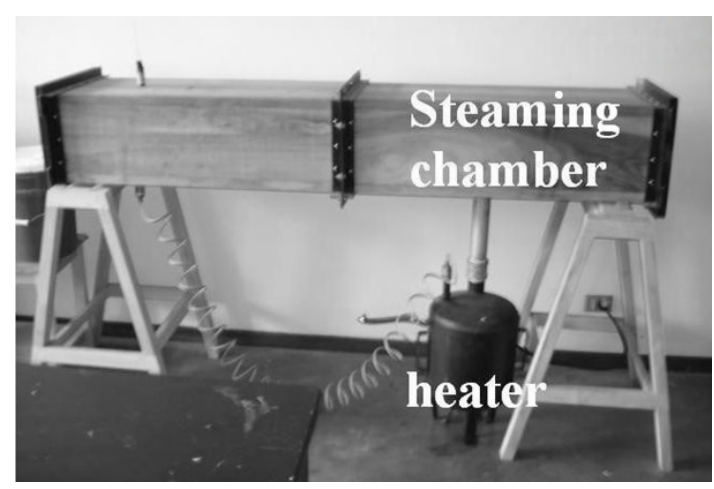

(a)

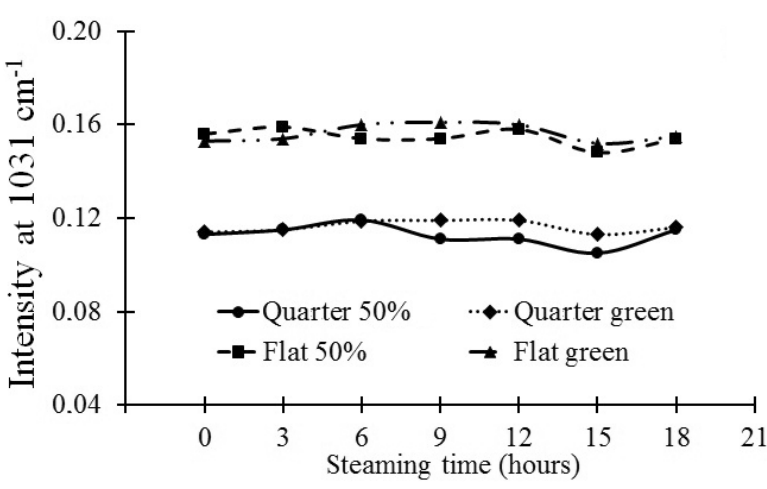

(b)

Fig. 1. (a) Pilot steaming chamber utilized and (b) intensity at $1031 \mathrm{~cm}^{-1}$ band at different steaming times in Tectona grandis wood with flat pattern and quarter pattern with different steaming times.

density was 475 trees $\cdot \mathrm{ha}^{-1}$, with an average diameter at breast height $(\mathrm{DBH})$ of $23 \mathrm{~cm}$ and $14 \mathrm{~m}$ height. The heartwood percentage at $\mathrm{DBH}$ varied from $65 \%$ to $80 \%$. Approximately, four $2.5 \mathrm{~m}$ long logs were extracted from the selected trees. Nine trees were selected from plantation because this number of trees are typically used for determining wood properties. $^{13}$

The logs were sawn using a grain pattern to produce 25-mm-thick boards, allowing for flat-grain- and quarter-grain-patterned boards. About 120 boards were selected, out of which 60 where flat-grain- and the remaining 60 were quarter-grain-patterned. The boards from each grain pattern were then separated into two groups of 30 boards each. One group patterned green condition - was stored to retain the moisture. A second group was air-dried to reach $50 \%$ MC. Once both conditions of MC were reached, seven test samples approximately $2.5 \mathrm{~cm}$ in width and $35 \mathrm{~cm}$ long were extracted from each one of the boards.

\subsection{Steam-drying treatment}

For each steam-drying test with water, 30 test samples of each grain pattern and moisture condition were used ( 7 steaming times $\times 2$ grain patterns $\times 2$ moisture conditions $\times 30$ samples $=840$ samples $)$. A steam pilot wooden chamber $(200 \mathrm{~cm} \times 30 \mathrm{~cm} \times$ $30 \mathrm{~cm}$ ) was used (Fig. 1) and the steam was provided by a 19-l water-heating tank. An electric resistance was employed to boil the water (Fig. 1).

Steam-drying treatments are described in Table 1; about seven different treatments were applied. For each grain pattern and for each moisture condition, four different baths were conducted. The treatments consist of one control sample and six treatments including steaming of the wood in six different drying times, with a difference of $3 \mathrm{~h}$ between them (Table 1). First, water steam was added into the chamber for a conditioning period of $3 \mathrm{~h}$ during which the chamber reaches approximately $70^{\circ} \mathrm{C}$. The wood to be steam-dried is separated into each grain pattern and moisture condition in seven packages of 30

Table 1. Description of the steam-drying treatments applied to Tectona grandis wood in plantations.

\begin{tabular}{lcl}
\hline No. & Steaming time $(\mathrm{h})$ & \multicolumn{1}{c}{ Descriptions } \\
\hline 1. & 0 & Control treatment, $0 \mathrm{~h}$ steaming and samples dried to $12 \% \mathrm{MC}$. \\
2. & 3 & Wood was steamed for $3 \mathrm{~h}$ and dried to $12 \% \mathrm{MC}$. \\
3. & 6 & Wood was steamed for $6 \mathrm{~h}$ and dried to $12 \% \mathrm{MC}$. \\
4. & 9 & Wood was steamed for $9 \mathrm{~h}$ and dried to $12 \% \mathrm{MC}$. \\
5. & 12 & Wood was steamed for $12 \mathrm{~h}$ and dried to $12 \% \mathrm{MC}$. \\
6. & 15 & Wood was steamed for $15 \mathrm{~h}$ and dried to $12 \% \mathrm{MC}$. \\
7. & 18 & Wood was steamed for $18 \mathrm{~h}$ and dried to $12 \% \mathrm{MC}$. \\
\hline
\end{tabular}

Notes: About $3 \mathrm{~h}$ of conditioning was applied in all treatments before initiating the steaming. 


\section{A. Berrocal et al.}

Table 2. Summary of FTIR bands observed between $800 \mathrm{~cm}^{-1}$ and $1800 \mathrm{~cm}^{-1}$ in steam-treated Tectona grandis wood surface.

\begin{tabular}{|c|c|c|c|}
\hline S. No. & Position $\left(\mathrm{cm}^{-1}\right)$ & Peak assignments & Structural polymers \\
\hline \multicolumn{4}{|c|}{ Peaks present in all Tectona grandis samples } \\
\hline 1. & 810 & $\mathrm{C}=\mathrm{O}$ & Glucomannan \\
\hline 2. & 1031 & $\mathrm{C}-\mathrm{O}$ stretch & Cellulose and hemicellulose \\
\hline 3. & 1053 & $\mathrm{C}-\mathrm{O}$ stretch & Cellulose and hemicellulose \\
\hline 4. & 1108 & Aromatic skeletal and $\mathrm{C}-\mathrm{O}$ stretch & Polysaccharides and lignin \\
\hline 5. & 1158 & $\mathrm{C}-\mathrm{O}-\mathrm{C}$ vibration & Cellulose and hemicellulose \\
\hline 6. & 1231 & $\mathrm{C}-\mathrm{O}$ of syringyl ring & Lignin \\
\hline 7. & 1318 & $\mathrm{C}-\mathrm{O}$ vibration & Lignin \\
\hline 8. & 1373 & $\mathrm{C}-\mathrm{H}$ deformation & Cellulose and hemicellulose \\
\hline 9. & 1419 & $\mathrm{C}-\mathrm{H}$ in-plane deformation with aromatic ring stretching & Lignin \\
\hline 10. & 1453 & $\mathrm{CH}$ deformation, asymmetry in $\mathrm{CH}_{3}$ and $\mathrm{CH}_{2}$ & Cellulose \\
\hline 16. & 1506 & Aromatic skeletal vibration $(\mathrm{C}=\mathrm{C})$ & Lignin \\
\hline 19. & 1595 & Aromatic skeletal vibration $(\mathrm{C}=\mathrm{C})$ & Lignin \\
\hline 24. & 1652 & $\begin{array}{l}\text { Conjugated } \mathrm{C}=\mathrm{O} \text { inquilines coupled with } \mathrm{C}=\mathrm{O} \text { stretching of } \\
\text { various groups }\end{array}$ & Hemicellulose \\
\hline 25. & 1717 & $\mathrm{C}=\mathrm{O}$ stretching & In the carboxylic acid in lignin \\
\hline 26. & 1733 & Conjugated $\mathrm{C}=\mathrm{O}$ & Xylan in hemicelluloses \\
\hline \multicolumn{4}{|c|}{ Peaks present in all quarter Tectona grandis wood samples } \\
\hline & 1616 & Aromatic skeletal vibration $(\mathrm{C}=\mathrm{C})$ & Tannin \\
\hline & 1635 & Aromatic skeletal vibration $(\mathrm{C}=\mathrm{C})$ & Tannin \\
\hline & 1675 & $\mathrm{C}=\mathrm{O}$ stretching in conjugated aromatic & Lignin \\
\hline
\end{tabular}

Source: Li et al. ${ }^{18}$ and Bonifazi et al. ${ }^{23}$

boards each. The control package is left without steam and the other six packages are introduced into the chamber once it has been conditioned and steaming continues. Every $3 \mathrm{~h}$, one package is taken out of the chamber and the wood is dried to reach $12 \%$ MC. The steaming time was selected according to previous research in tropical species. ${ }^{16}$

\subsection{Measurement and analysis of the FTIR spectra of the surface of the wood}

Once the steam-drying treatment with different times $(0,3,6,9,12,15$ and $18 \mathrm{~h})$ is finished for each grain pattern, three different boards were taken randomly from each time and grain pattern and two small samples were extracted from the surface of the board. Their dimensions (width $\times$ length $\times$ thickness) were $1 \mathrm{~cm} \times 1 \mathrm{~cm} 2 \times 1 \mathrm{~mm}$ (this part is in the surface of the board). The FTIR spectra of the three samples were measured on the surface of the wood by means of a Nicolet 380 FTIR spectrometer (Thermo Scientific) using a single reflectance ATR cell (equipped with a diamond crystal). All data were recorded at room temperature, in the spectral range of $4000-700 \mathrm{~cm}^{-1}$, by accumulating 64 scans with a resolution of $1 \mathrm{~cm}^{-1}$.

The FTIR spectra obtained were then processed by the softwares Spotlight 1.5.1, Hyperview 3.2 and Spectrum 6.2.0 developed by Perkin Elmer, Inc. Baseline correction was applied at $1800-800 \mathrm{~cm}^{-1}$ and the main components in this vibration band were identified. This band was selected as several studies have identified it as the range where the variation in the changes of the surface of the wood mostly occurs, ${ }^{17,18}$ which are described in Table 2 . The height of each peak for each steaming time was recorded and standardized taking the $I_{1031}$ band as a reference, given its stableness in all the conditions studied. The ratio between the various peaks in the range of $800-1800 \mathrm{~cm}^{-1}$ (Eq. (1)) was then calculated, as well as the band at $1031 \mathrm{~cm}^{-1}$ (1) all times and different grain patterns. This band was selected because large differences were not observed among treatments. The intensity was $0.155 \mathrm{~cm}^{-1}$ in wood with flat pattern and $0.118 \mathrm{~cm}^{-1}$ in wood with radial pattern with different steaming times (Fig. 1(b)). 
Ratio of intensity $\left(I_{n} / T_{1031}\right)$

$$
=\frac{\text { Intensity of peaks between } 1800 \text { to } 800 \mathrm{~cm}^{-1}}{\text { Intensity of } 1031 \mathrm{~cm}^{-1}} \text {. }
$$

\subsection{Surface color measurement and determination of color change}

For all conditions of MC and grain pattern, color was evaluated before the steam-drying treatment. Wood surface color was also determined after each steamdrying treatment once the wood reached approximately $12 \%$ MC. The MiniScan XE Plus ${ }^{19}$ spectrophotometer was utilized to obtain the values of the standardized chromatological system CIEL $a^{*} b^{*}$. The range for this measure is from $400 \mathrm{~nm}$ to $700 \mathrm{~nm}$, with $11 \mathrm{~mm}$ opening at the point of measurement. The observation of the reflection included the specular component (SCI mode), at an angle of $10^{\circ}$, which is normal for the surface of the specimen (D65/10); a visual range of $2^{\circ}$ (Standard observer, CIE 1931) and an illumination standard of D65 (corresponding to daylight at $6500 \mathrm{~K}$ ).

In the analysis of color change, the change in the color parameters $\left(L^{*}, a^{*}, b^{*}\right)$ was calculated first with the aid of Eq. (2).

$$
\Delta P=P_{b}-P_{a}
$$

where $\Delta P=$ represents the absolute value of wood color parameters $\left(L^{*}, a^{*}\right.$ or $\left.b^{*}\right)$ change between after and before steaming process. $P_{b}$ is the wood color parameters $\left(L^{*}, a^{*}\right.$ or $\left.b^{*}\right)$ after the steam-drying treatment and $P_{a}$ is the wood color parameters $\left(L^{*}\right.$, $a^{*}$ or $b^{*}$ ) before the steam-drying treatment.

Following, color change was determined, utilizing the parameter $\Delta E^{*}$ calculated according to the ASTM D 2244 standard $^{20}$ whose formula is detailed in Eq. (3). The color difference $\left(\Delta E^{*}\right)$ was determined for (i) color change that occurred in the wood surface, taking the color before steam-drying treatment as a model, (ii) color change after the steam-drying treatment and (iii) the surface color of wood coming from the natural forest and mature trees, ${ }^{5}$ aimed at establishing the treatment with the lowest color difference with respect to commonly commercialized wood of natural forests (over 100year-old).

$$
\Delta E^{*}=\sqrt{\left(\Delta L^{*}\right)^{2}+\left(\Delta a^{*}\right)^{2}+\left(\Delta b^{*}\right)^{2}},
$$

where $\Delta E^{*}=$ wood color difference, $\Delta L=L^{*}$ before steaming $-L^{*}$ after steaming; $\Delta a=a^{*}$ before steaming $-a^{*}$ after steaming and $\Delta b=b^{*}$ before steaming $-b^{*}$ after steaming. For color change in (ii), the values of $L^{*}, a^{*}$ and $b^{*}$ after steaming were substituted by $L^{*}=44.94, \quad a^{*}=12.44 \quad$ and $b^{*}=24.26$, which correspond to the color parameters measured in the wood coming from the natural forest.

\subsection{Statistical analysis}

In each grain pattern (flat or quarter pattern), a variance analysis (ANOVA) was applied. The aim was to know whether differences in the parameter before and after steam-drying treatment exist. The model included the following sources of variation: steaming time $(t)$ at seven levels $(0,3,6,9,12,15$ and $18 \mathrm{~h}$ ), MC at two levels (green and 50\%) and interaction between $t$ and MC. The SAS GLM procedure (SAS Institute, Inc.) was used to conduct the analysis of variance.

In addition, a forward stepwise analysis was applied to determine the effects of the three color parameters $\Delta a^{*}, \Delta b^{*}$ and $\Delta L^{*}$ on the teak wood color before and after steam-drying treatment, with wood from natural forests as a model. For the FTIR spectra, a scatter plot and then regression analysis were conducted taking into account the steaming time (x-axis) and the intensity ratio values (y-axis). The change in the intensity ratio peak assignment was thus observed for the different steaming times.

\section{Results and Discussion}

\subsection{Surface chemistry of steamed Tectona grandis wood measured by means of the FTIR spectra}

Although the entire range of the spectra (4000$400 \mathrm{~cm}^{-1}$ ) was not presented, signals were present in all the steaming periods and grain patterns in the region $3500-2500 \mathrm{~cm}^{-1}$, corresponding to stretching of O-H group (close to $3400 \mathrm{~cm}^{-1}$ ), $\mathrm{C}-\mathrm{H}$ and $\mathrm{CH}_{2}$ asymmetric and symmetric stretching $\left(2940 \mathrm{~cm}^{-1}\right.$ and $2906 \mathrm{~cm}^{-1}$, respectively) of the combination of cellulose, hemicelluloses and lignin. ${ }^{21,22}$ 
Peak assignments varied slightly in each type of wood (flat or quarter grain) and MC (green and 50\%) in the band studied $\left(1000-1800 \mathrm{~cm}^{-1}\right)$. Table 2 summarizes in its first part the common peaks for different types of wood treatment and presents the peak assignments, as well as to which polymer they are assigned, based on reports from Moore and Owen, ${ }^{21} \mathrm{Li}$ et al. ${ }^{18}$ and Bonifazi et al. ${ }^{23}$

The infrared spectra of the different treatments studied had revealed that the positions of most bands and their intensities in the fingerprint region are similar while some are slightly different (Fig. 2). It was found that the chemical components with the signal at 810, 1035, 1053, 1108, 1158, 1231, 1318, 1373 (C-H in-plane deformation for polysaccharides), 1419 (C-H in-plane deformation), 1453 (C-H deformation and aromatic skeletal vibrations), 1506 (aromatic skeletal vibrations), 1558, 1595 (aromatic skeletal vibrations), 1652 (conjugated carbonyl), 1683, 1700, 1717 and $1733 \mathrm{~cm}^{-1}$ (stretching of the carbonyl group $\mathrm{C}=\mathrm{O}$ ) are present in all surfaces in the different treatments (Figs. 2(a) and 2(b)), while chemical components with the signal at 1540,1554,1575, 1616 , 1635, 1675 and $1695 \mathrm{~cm}^{-1}$ were observed in the FTIR spectra of the radial samples when the wood was not steam-treated (Figs. 2(c) and 2(d)).

As for the variation of the intensity ratio for each one of the peaks within the band of $800-1800 \mathrm{~cm}^{-1}$, it was observed that the signal at $1158,1231,1373$ and $1419 \mathrm{~cm}^{-1}$ did not show any trend in the index, due to the treatment of the wood with different steaming times and grain patterns of the boards. Meanwhile, the signals at 1053, 1108, 1453, 1506, 1536, 1558, 1595, 1652, 1683, 1700 and 1733 $\mathrm{cm}^{-1}$ showed diminution of the index of vibration regarding the steaming time (Figs. 3(a), 3(b) and 3(d)$3(\mathrm{l})$ ). The only vibration where the index augmented was $1318 \mathrm{~cm}^{-1}$ (Fig. 3(c)). In the same way, the variation coefficient varied from $10 \%$ to $22 \%$ at different intensities (Table 3) and any tendency was not found.

As for the signals at 1540, 1554, 1575, 1616, 1635, 1675 and $1695 \mathrm{~cm}^{-1}$, present in the FTIR spectra of the quarter pattern samples of wood not treated with steam, they diminished or disappeared once the wood was steam-treated (Figs. 3(c) and 3(d)).

As for the bands associated to cellulose (1053, 1373,1158 and $1453 \mathrm{~cm}^{-1}$ ), a decrease in the signals in the band between $1053 \mathrm{~cm}^{-1}$ and $1453 \mathrm{~cm}^{-1}$ (Figs. 3(a) and 3(d)) was observed, while the signals at $1318 \mathrm{~cm}^{-1}$ increased (Fig. 3(c)). Meanwhile, the signals 1373 and $1158 \mathrm{~cm}^{-1}$ did not show any modifications. The diminutions observed in the cellulose indicate either the occurrence of changes in its structure or the formation of other compounds, such as the formation of aliphatic alcohols during steaming, ${ }^{18}$ which becomes evident in the change of the intensity at $1055 \mathrm{~cm}^{-1}$.

A major aspect to emphasize of the steaming process in Tectona grandis wood, is the variation in the intensity of the signals at $1053 \mathrm{~cm}^{-1}$ (Fig. 3(a)) and the increment in the intensity at $1318 \mathrm{~cm}^{-1}$ (Fig. 3(c)). These changes are designated to increase the glucose ring stretching vibration, and may be due to the cleavage and dehydration of amorphous carbohydrates and/or crystallization of the paracrystalline region of cellulose. ${ }^{14}$ The increment in the intensity ratio in the signal at $1318 \mathrm{~cm}^{-1}$ (Fig. 3(c)) indicates a decrease in the percentage of cellulose crystallinity. ${ }^{18}$ This reveals that the amorphous regions of the teak wood increase with the steaming time. ${ }^{14}$

The changes in the intensity of the signals associated with hemicelluloses and lignin - shown in peaks at $1733 \mathrm{~cm}^{-1}$ (O-acetyl-4-O-methylglucurono-xylan) (Fig. 3(l)), and $1595 \mathrm{~cm}^{-1}$ (belonging to $\mathrm{C}=\mathrm{O}$ stretching vibrations in the carboxyl group of glucuronic acid unit in xylan) (Fig. $3(\mathrm{~h})$ ) - to the aromatic skeletal vibrations plus $\mathrm{C}-\mathrm{O}$ stretch of lignin ${ }^{24}$ and to vibrations caused by the equatorially aligned hydrogen at the $\mathrm{C}_{2}$ atom in the mannose residue of glucomannan, ${ }^{15}$ clearly indicating the changes in the structure of the hemicelluloses and the structure of the lignin of teak wood as a result of steaming.

There is a important reference at $810 \mathrm{~cm}^{-1}$ intensity. Any signal was found in this intensity for quarter, flat or moisture conditions (Fig. 4). According to Guo et al., ${ }^{12}$ in softwood species, the $810 \mathrm{~cm}^{-1}$, coorrespondent to $\mathrm{C}=\mathrm{O}$ in the $\mathrm{O}=\mathrm{C}-\mathrm{OH}$ group of the glucuronic acid unit of the glucomannan band, decreased by $47 \%$ in steam wood. They affirmed that this chemical change might be related to the effect of the compression which presumably created more porous structures in earlywood due to the heavy distortion of the cell wall but caused a closure of lumens in latewood. Such pores, small cracks and more open lumens would facilitate penetration of steam, leading to higher degradation of hemicellulose structures in the earlywood. ${ }^{12}$ However, this structural change was not found in Tectona grandis, showing with this 


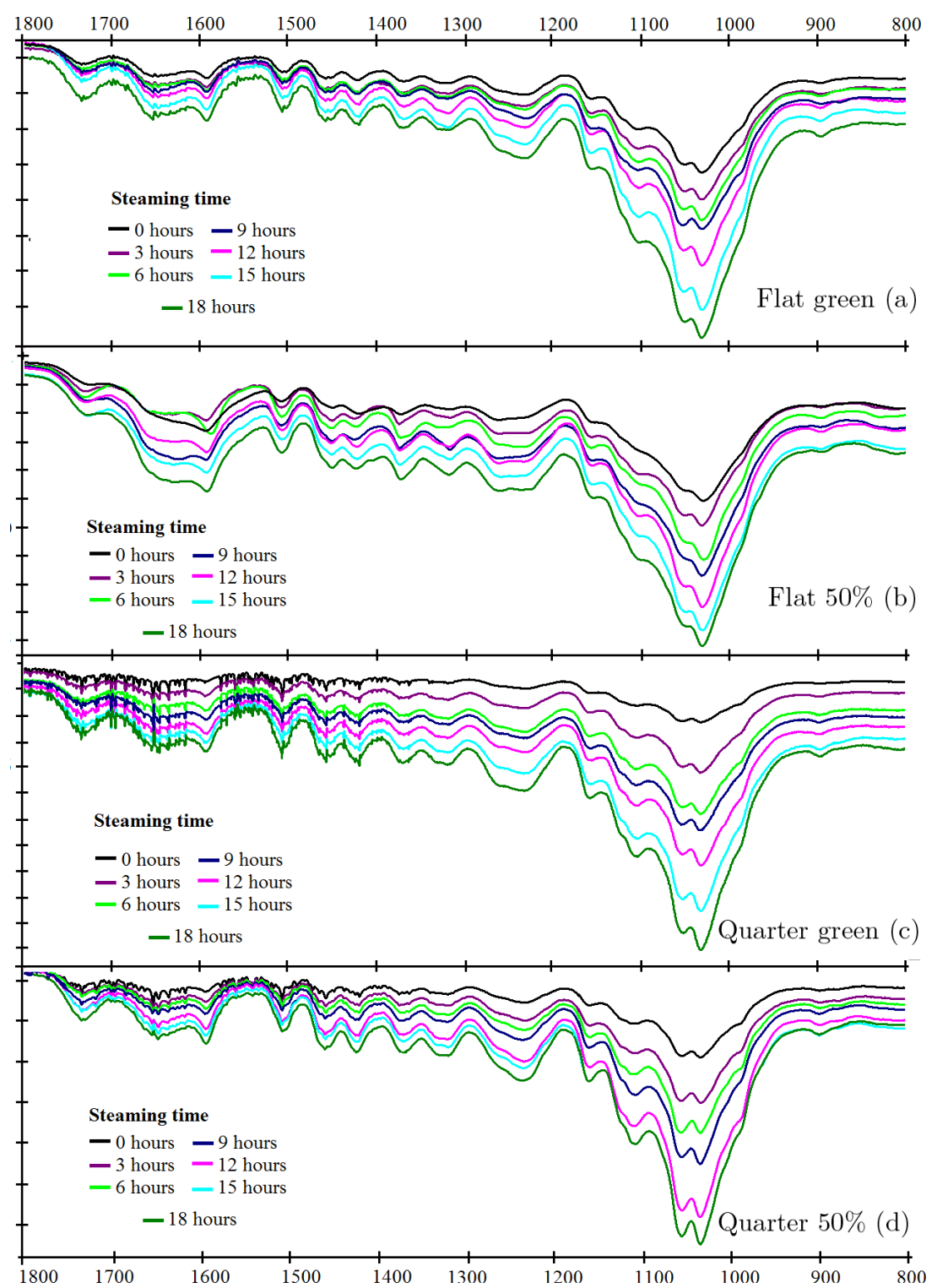

Fig. 2. FTIR spectra of steamed Tectona grandis wood with flat pattern (a) and (b) and quarter pattern (c) and (d) with different steaming periods.

result the differences between softwood and hardwood species.

Nevertheless, those changes behaved differently with the steaming time and the grain pattern. For example, with the change of intensity at $1595 \mathrm{~cm}^{-1}$ (Fig. 3(h)), associated to lignin, the main change occurs at $3 \mathrm{~h}$ of steaming, with no more changes thereafter. On the other hand, regarding the intensity associated to xylan, an increment in the ratio $\mathrm{I}_{1733} / \mathrm{I}_{1031}$ is observed with the steaming time (Fig. 3(1)), indicating further change in the structure of this hemicellulose due to the steaming process.
The intensity of vibration of the xylan band at $1453 \mathrm{~cm}^{-1}$ (Fig. 3(d)) ascribed to $\mathrm{CH}_{2}$ symmetric bending on the xylose ring $^{15}$ only showed small changes for the different steaming times. Because the $1456 \mathrm{~cm}^{-1}$ peak, associated to the xylan backbone, was nearly unaffected, it is probable that no major degradation of the xylan backbone had occurred, and that the primary effect on the xylan was a side group splitting. ${ }^{12}$

The larger decrease in the relative signal between $1596 \mathrm{~cm}^{-1}$ to $1733 \mathrm{~cm}^{-1}$ (Figs. $3(\mathrm{~h})-3(\mathrm{l})$ ), especially during the first $3 \mathrm{~h}$ of steaming of the flat pattern 
A. Berrocal et al.
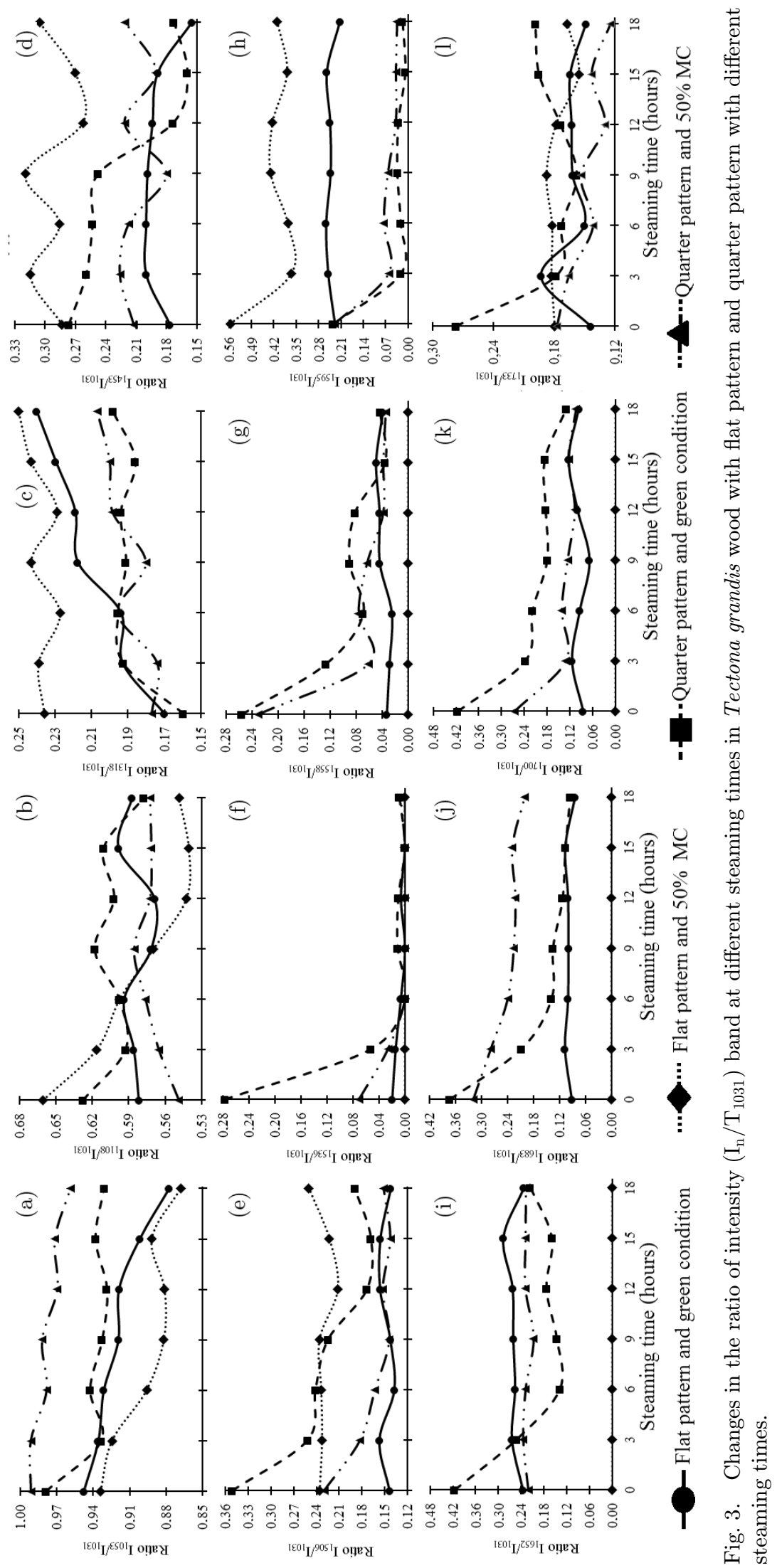

1550091-8 
Table 3. Coefficient of variation (\%) of change in the ratio of intensity $\left(\mathrm{I}_{\mathrm{n}} / T 1031\right)$ band at different steaming times in Tectona grandis wood with flat pattern and quarter pattern with different steaming times.

\begin{tabular}{|c|c|c|c|c|c|c|c|c|c|c|c|}
\hline \multirow[b]{2}{*}{ IT } & \multirow[b]{2}{*}{$\mathrm{TS}(\mathrm{h})$} & \multicolumn{2}{|c|}{ Radial grain } & \multicolumn{2}{|c|}{ Tangential grain } & \multirow[b]{2}{*}{ IT } & \multirow[b]{2}{*}{$\mathrm{TS}(\mathrm{h})$} & \multicolumn{2}{|c|}{ Radial grain } & \multicolumn{2}{|c|}{ Tangential grain } \\
\hline & & $50 \%$ & Green & $50 \%$ & Green & & & Green & $50 \%$ & Green & $50 \%$ \\
\hline \multirow[t]{7}{*}{1053} & 0 & 16 & 23 & 21 & 17 & \multirow[t]{7}{*}{1108} & 0 & 19 & 23 & 13 & 20 \\
\hline & 3 & 15 & 14 & 14 & 19 & & 3 & 15 & 16 & 15 & 20 \\
\hline & 6 & 22 & 20 & 15 & 24 & & 6 & 15 & 32 & 16 & 23 \\
\hline & 9 & 19 & 29 & 15 & 22 & & 9 & 12 & 30 & 13 & 22 \\
\hline & 12 & 18 & 24 & 13 & 20 & & 12 & 18 & 26 & 20 & 24 \\
\hline & 15 & 9 & 18 & 14 & 31 & & 15 & 12 & 19 & 19 & 35 \\
\hline & 18 & 17 & 21 & 16 & 22 & & 18 & 12 & 23 & 23 & 21 \\
\hline \multirow[t]{7}{*}{1318} & 0 & 17 & 10 & 11 & 21 & \multirow[t]{7}{*}{1453} & 0 & 22 & 15 & 21 & 18 \\
\hline & 3 & 23 & 13 & 15 & 15 & & 3 & 21 & 17 & 21 & 20 \\
\hline & 6 & 20 & 24 & 17 & 22 & & 6 & 20 & 16 & 20 & 18 \\
\hline & 9 & 20 & 21 & 17 & 18 & & 9 & 16 & 17 & 18 & 19 \\
\hline & 12 & 20 & 15 & 18 & 24 & & 12 & 22 & 18 & 20 & 21 \\
\hline & 15 & 18 & 15 & 13 & 21 & & 15 & 16 & 17 & 18 & 17 \\
\hline & 18 & 18 & 14 & 14 & 21 & & 18 & 18 & 21 & 22 & 20 \\
\hline \multirow[t]{7}{*}{1506} & 0 & 16 & 12 & 24 & 21 & \multirow[t]{7}{*}{1536} & 0 & 15 & 15 & 17 & 18 \\
\hline & 3 & 12 & 19 & 19 & 20 & & 3 & 21 & 15 & 16 & 16 \\
\hline & 6 & 19 & 17 & 17 & 20 & & 6 & 22 & 16 & 18 & 17 \\
\hline & 9 & 16 & 22 & 26 & 23 & & 9 & 19 & 14 & 20 & 20 \\
\hline & 12 & 25 & 19 & 19 & 24 & & 12 & 16 & 17 & 15 & 13 \\
\hline & 15 & 17 & 17 & 22 & 21 & & 15 & 22 & 20 & 17 & 16 \\
\hline & 18 & 14 & 25 & 24 & 21 & & 18 & 19 & 19 & 12 & 14 \\
\hline \multirow[t]{7}{*}{1558} & 0 & 15 & 12 & 15 & 12 & \multirow[t]{7}{*}{1595} & 0 & 15 & 12 & 15 & 17 \\
\hline & 3 & 13 & 11 & 15 & 10 & & 3 & 10 & 15 & 17 & 19 \\
\hline & 6 & 12 & 11 & 14 & 10 & & 6 & 13 & 17 & 18 & 18 \\
\hline & 9 & 11 & 11 & 12 & 13 & & 9 & 17 & 18 & 16 & 16 \\
\hline & 12 & 14 & 13 & 15 & 11 & & 12 & 14 & 11 & 16 & 13 \\
\hline & 15 & 11 & 13 & 13 & 13 & & 15 & 19 & 14 & 15 & 18 \\
\hline & 18 & 11 & 12 & 13 & 9 & & 18 & 21 & 12 & 16 & 17 \\
\hline \multirow[t]{7}{*}{1652} & 0 & 17 & 13 & 17 & 13 & \multirow[t]{7}{*}{1683} & 0 & 13 & 23 & 17 & 20 \\
\hline & 3 & 16 & 12 & 19 & 17 & & 3 & 16 & 18 & 18 & 20 \\
\hline & 6 & 17 & 17 & 16 & 17 & & 6 & 17 & 18 & 18 & 20 \\
\hline & 9 & 17 & 16 & 17 & 19 & & 9 & 15 & 20 & 20 & 21 \\
\hline & 12 & 14 & 11 & 15 & 19 & & 12 & 19 & 22 & 22 & 20 \\
\hline & 15 & 15 & 13 & 15 & 19 & & 15 & 15 & 21 & 22 & 19 \\
\hline & 18 & 18 & 12 & 15 & 16 & & 18 & 15 & 21 & 19 & 19 \\
\hline \multirow[t]{7}{*}{1700} & 0 & 19 & 22 & 22 & 12 & \multirow[t]{7}{*}{1703} & 0 & 19 & 14 & 16 & 12 \\
\hline & 3 & 15 & 19 & 23 & 14 & & 3 & 15 & 17 & 13 & 14 \\
\hline & 6 & 14 & 19 & 20 & 12 & & 6 & 14 & 13 & 17 & 12 \\
\hline & 9 & 16 & 15 & 18 & 12 & & 9 & 16 & 15 & 18 & 12 \\
\hline & 12 & 13 & 21 & 23 & 11 & & 12 & 13 & 13 & 13 & 14 \\
\hline & 15 & 19 & 16 & 23 & 12 & & 15 & 14 & 16 & 13 & 13 \\
\hline & 18 & 14 & 22 & 15 & 14 & & 18 & 14 & 13 & 15 & 13 \\
\hline
\end{tabular}

Notes: IT: intensity; TS: time of steaming.

samples, and the steady diminution in quarter pattern samples (Fig. 3(h)), in combination with the lower change in intensity at $1506 \mathrm{~cm}^{-1}$ (Fig. 3(e)), indicate that a loss of the $\mathrm{C}=\mathrm{O}$ group linked to the aromatic skeleton of lignin has probably occurred.
This could indicate that cross-links have been formed between aromatic units in the lignin. Obviously, different behaviors are observed for hemicelluloses and lignin in relation to the degradation under steam conditions. This points to the degradation of 

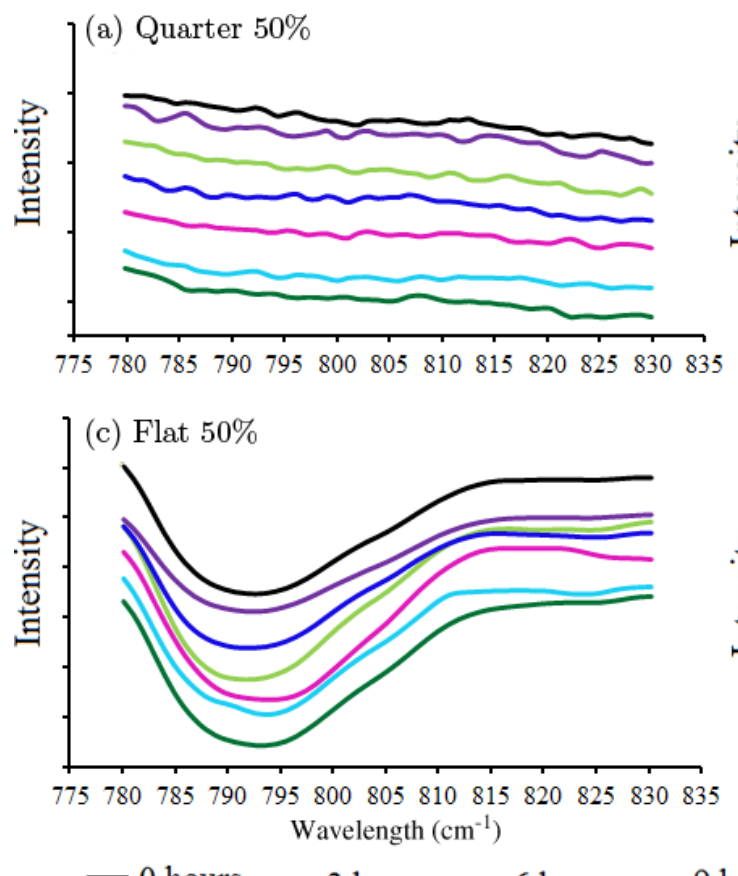
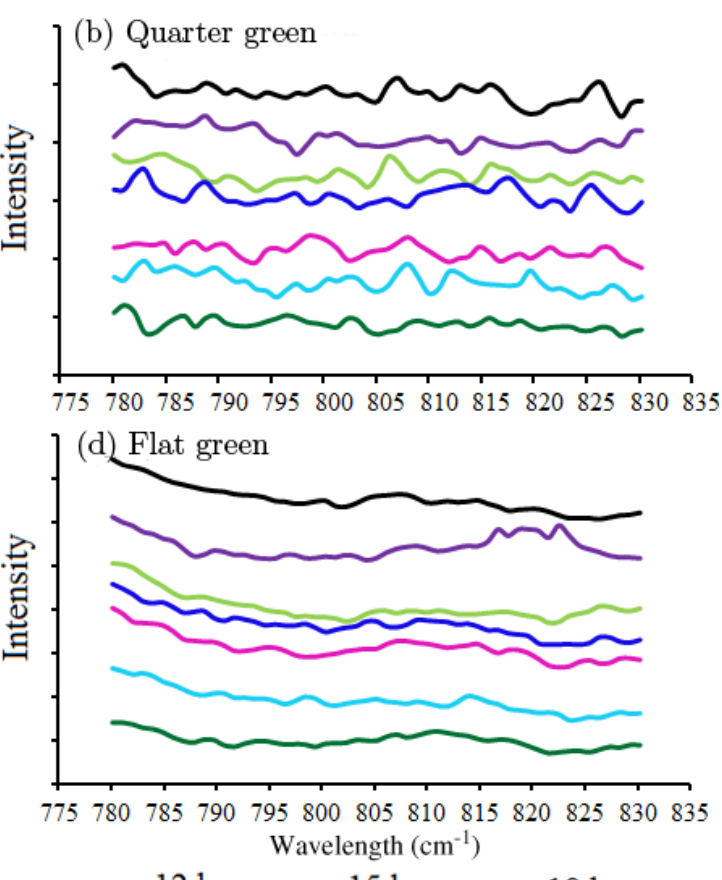

Fig. 4. FTIR spectra from $775 \mathrm{~cm}^{-1}$ to $835 \mathrm{~cm}^{-1}$ of steamed Tectona grandis wood with quarter pattern (a) and (b) and flat pattern (c) and (d) with different steaming periods.

hemicelluloses and lignin following different pathways. Lignin cross-linking is probably a radical reaction $^{25}$ which might be favored by the increased density of the wood material while the hemicellulose degradation is probably more favored by the more open access to dissolution of carbohydrates. ${ }^{26}$

\subsection{Color change in Tectona grandis surface wood induced by steaming and drying}

Wood color before the steam-drying treatment showed differences by grain pattern and MC. Flat pattern boards in the two moisture conditions studied (green and 50\%) presented lower values of lightness $\left(L^{*}\right)$ and higher values of redness $\left(a^{*}\right)$ relative to quarter pattern boards. As for yellowness $\left(b^{*}\right)$, the color showed no difference between flat and quarter patterns before steaming (Table 4). Differences in color by grain pattern have been pointed out for several species. ${ }^{27,28}$

The differences in the color parameters $L^{*}$ and $a^{*}$ and the lack of difference among parameter $b^{*}$, may be explained by two studies: (i) according to Gierlinger et al. ${ }^{29}$ redness $\left(a^{*}\right)$ and lightness $\left(L^{*}\right)$ indexes are more correlated with wood extractive content, while the yellowness index is primarily related to the lignin's photochemistry; (ii) on the other hand, Valverde and Moya ${ }^{30}$ mention that many extractives settle in the radial parenchyma cells, which means that in a radial surface, color will change more than that in a tangential surface. Therefore, $L^{*}$ and $a^{*}$ should be expected to change in green condition, since the extractives are exposed and the lignin still has not begun to photodegrade as the drying process has not started, which explains why the differences in $b^{*}$ are not observed in flat and quarter pattern boards.

The magnitude of the color parameters changed in the different steaming-drying times (Table 4 ), $L^{*}$ in particular, followed by $b^{*}$ and, to a lesser extent, $a^{*}$. The steam-drying treatment increased lightness $\left(L^{*}\right)$ significantly in flat and quarter grain green-condition boards (Table 4); however, when the board presents MC above $50 \%$, the effect is the opposite, significantly reducing $L^{*}$.

This behavior is reflected in the differential values of luminosity $\left(\Delta L^{*}\right) . \Delta L^{*}$ values in flat and quarter pattern steam-dried woods were positive for wood in green condition, as opposed to $50 \% \mathrm{MC}$ wood, where $\Delta L^{*}$ values were negative (Figs. $5(\mathrm{a})$ and $5(\mathrm{~b})$ ). No 
Surface Chemical and Color Characterization of Steam-Dried Tectona grandis Wood

Table 4. Lab system color parameters of Tectona grandis wood before and after the different steaming-drying times.

\begin{tabular}{|c|c|c|c|c|c|c|c|c|c|}
\hline \multirow[b]{2}{*}{$\mathrm{MC}$} & \multirow[b]{2}{*}{ Color parameters } & \multirow[b]{2}{*}{ Time } & \multicolumn{7}{|c|}{ Steaming time $(\mathrm{h})$} \\
\hline & & & 0 & 3 & 6 & 9 & 12 & 15 & 18 \\
\hline & & & & Flat pa & tern & & & & \\
\hline \multirow[t]{6}{*}{ Green } & $L^{*}$ & Before & $40.1 \mathrm{~A}$ & $41.5 \mathrm{~A}$ & $43.4 \mathrm{~A}$ & $43.7 \mathrm{~A}$ & $42.2 \mathrm{~A}$ & $41.2 \mathrm{~A}$ & $42.7 \mathrm{~A}$ \\
\hline & & After & $55.2 \mathrm{~B}$ & $53.9 \mathrm{~B}$ & $54.2 \mathrm{~B}$ & $53.5 \mathrm{~B}$ & $55.7 \mathrm{~B}$ & $55.5 \mathrm{~B}$ & $54.4 \mathrm{~B}$ \\
\hline & $a^{*}$ & Before & $11.7 \mathrm{~A}$ & $10.8 \mathrm{~A}$ & $10.4 \mathrm{~A}$ & $11.1 \mathrm{~A}$ & $11.3 \mathrm{~A}$ & $11.5 \mathrm{~A}$ & $11.1 \mathrm{~A}$ \\
\hline & & After & $11.0 \mathrm{~A}$ & $11.2 \mathrm{~A}$ & $10.4 \mathrm{~A}$ & $9.9 \mathrm{~A}$ & $10.3 \mathrm{~A}$ & $9.9 \mathrm{~B}$ & $9.6 \mathrm{~B}$ \\
\hline & $b^{*}$ & Before & $29.0 \mathrm{~A}$ & $28.4 \mathrm{~A}$ & $29.1 \mathrm{~A}$ & $28.9 \mathrm{~A}$ & $29.4 \mathrm{~A}$ & $28.3 \mathrm{~A}$ & $29.4 \mathrm{~A}$ \\
\hline & & After & $27.8 \mathrm{~A}$ & $25.4 \mathrm{~B}$ & $27.0 \mathrm{~B}$ & $26.2 \mathrm{~B}$ & $27.9 \mathrm{~A}$ & $26.5 \mathrm{~B}$ & $25.6 \mathrm{~B}$ \\
\hline \multirow{7}{*}{$50 \% \mathrm{MC}$} & $L^{*}$ & Before & $56.5 \mathrm{~A}$ & $53.5 \mathrm{~A}$ & $54.9 \mathrm{~A}$ & $55.1 \mathrm{~A}$ & $55.4 \mathrm{~A}$ & $57.4 \mathrm{~A}$ & $55.8 \mathrm{~A}$ \\
\hline & & After & $51.2 \mathrm{~B}$ & $50.5 \mathrm{~B}$ & $50.4 \mathrm{~B}$ & $51.7 \mathrm{~B}$ & $51.4 \mathrm{~B}$ & $50.0 \mathrm{~B}$ & $50.2 \mathrm{~B}$ \\
\hline & $a^{*}$ & Before & $8.1 \mathrm{~A}$ & $8.0 \mathrm{~A}$ & $8.2 \mathrm{~A}$ & $7.8 \mathrm{~A}$ & $8.0 \mathrm{~A}$ & $7.4 \mathrm{~A}$ & $7.3 \mathrm{~A}$ \\
\hline & & After & $9.4 \mathrm{~B}$ & $9.6 \mathrm{~B}$ & $9.1 \mathrm{~A}$ & $9.4 \mathrm{~B}$ & $9.3 \mathrm{~B}$ & $8.4 \mathrm{~B}$ & $8.5 \mathrm{~A}$ \\
\hline & $b^{*}$ & Before & $22.9 \mathrm{~A}$ & $23.8 \mathrm{~A}$ & $25.6 \mathrm{~A}$ & $25.7 \mathrm{~A}$ & $27.6 \mathrm{~A}$ & $27.8 \mathrm{~A}$ & $27.7 \mathrm{~A}$ \\
\hline & & After & $23.8 \mathrm{~A}$ & $25.7 \mathrm{~B}$ & $26.3 \mathrm{~A}$ & $28.6 \mathrm{~B}$ & $29.0 \mathrm{~A}$ & $28.1 \mathrm{~A}$ & $28.4 \mathrm{~A}$ \\
\hline & \multicolumn{9}{|c|}{ Quarter pattern } \\
\hline \multirow[t]{6}{*}{ Green } & $L^{*}$ & Before & $45.4 \mathrm{~A}$ & $46.6 \mathrm{~A}$ & $43.3 \mathrm{~A}$ & $45.2 \mathrm{~A}$ & $46.3 \mathrm{~A}$ & $45.2 \mathrm{~A}$ & $43.6 \mathrm{~A}$ \\
\hline & & After & $54.5 \mathrm{~B}$ & $57.3 \mathrm{~B}$ & $56.6 \mathrm{~B}$ & $57.5 \mathrm{~B}$ & $56.1 \mathrm{~B}$ & $55.1 \mathrm{~B}$ & $53.7 \mathrm{~B}$ \\
\hline & $a^{*}$ & Before & $9.1 \mathrm{~A}$ & $9.4 \mathrm{~A}$ & $10.3 \mathrm{~A}$ & $9.8 \mathrm{~A}$ & $9.2 \mathrm{~A}$ & $9.5 \mathrm{~A}$ & $10.4 \mathrm{~A}$ \\
\hline & & After & $8.7 \mathrm{~A}$ & $8.9 \mathrm{~A}$ & $9.4 \mathrm{~A}$ & $9.0 \mathrm{~A}$ & $8.6 \mathrm{~A}$ & $7.8 \mathrm{~B}$ & $7.6 \mathrm{~B}$ \\
\hline & $b^{*}$ & Before & $29.9 \mathrm{~A}$ & $29.4 \mathrm{~A}$ & $28.5 \mathrm{~A}$ & $29.1 \mathrm{~A}$ & $29.7 \mathrm{~A}$ & $29.1 \mathrm{~A}$ & $27.1 \mathrm{~A}$ \\
\hline & & After & $27.8 \mathrm{~B}$ & $27.5 \mathrm{~B}$ & $26.5 \mathrm{~B}$ & $28.1 \mathrm{~A}$ & $27.3 \mathrm{~B}$ & $25.3 \mathrm{~B}$ & $24.3 \mathrm{~B}$ \\
\hline \multirow[t]{6}{*}{$50 \% \mathrm{MC}$} & $L^{*}$ & Before & $61.3 \mathrm{~A}$ & $62.7 \mathrm{~A}$ & $62.5 \mathrm{~A}$ & $62.1 \mathrm{~A}$ & $62.5 \mathrm{~A}$ & $62.2 \mathrm{~A}$ & $61.5 \mathrm{~A}$ \\
\hline & & After & $60.2 \mathrm{~A}$ & $60.5 \mathrm{~B}$ & $60.2 \mathrm{~B}$ & $59.5 \mathrm{~B}$ & $57.5 \mathrm{~B}$ & $56.0 \mathrm{~B}$ & $54.4 \mathrm{~B}$ \\
\hline & $a^{*}$ & Before & $8.4 \mathrm{~A}$ & $8.1 \mathrm{~A}$ & $9.1 \mathrm{~A}$ & $9.0 \mathrm{~A}$ & $8.7 \mathrm{~A}$ & $8.5 \mathrm{~A}$ & $8.7 \mathrm{~A}$ \\
\hline & & After & $8.8 \mathrm{~A}$ & $8.3 \mathrm{~A}$ & $8.6 \mathrm{~A}$ & $8.8 \mathrm{~A}$ & $8.2 \mathrm{~A}$ & $8.0 \mathrm{~A}$ & $8.2 \mathrm{~A}$ \\
\hline & $b^{*}$ & Before & $27.8 \mathrm{~A}$ & $30.9 \mathrm{~A}$ & $27.8 \mathrm{~A}$ & $27.5 \mathrm{~A}$ & $26.8 \mathrm{~A}$ & $29.5 \mathrm{~A}$ & $29.1 \mathrm{~A}$ \\
\hline & & After & $29.2 \mathrm{~A}$ & $28.6 \mathrm{~A}$ & $28.3 \mathrm{~A}$ & $28.4 \mathrm{~A}$ & $26.6 \mathrm{~A}$ & $25.8 \mathrm{~B}$ & $24.5 \mathrm{~B}$ \\
\hline
\end{tabular}

Notes: MC: moisture content.

defined behavior was observed in flat pattern among the different times (Fig. 5(a)). The lowest value of $\Delta L^{*}$ in flat pattern boards was observed during the $9 \mathrm{~h}$ of steam-drying and in the $3 \mathrm{~h}$ of steaming, for green-condition wood and $50 \% \mathrm{MC}$, respectively (Fig. 5(a)). For quarter pattern board, the $\Delta L^{*}$ values were not the lowest, after $12 \mathrm{~h}$ of steaming of the green-condition wood, while an increase in the steaming time in $50 \% \mathrm{MC}$ wood was observed (Fig. 5(b)).

Meanwhile, the parameter of redness $\left(a^{*}\right)$ was statistically unaffected in flat and quarter pattern boards in green condition between $0 \mathrm{~h}$ and $12 \mathrm{~h}$ of steaming-drying. Nevertheless, in the 15- and 18-h steaming treatment, the parameter $a^{*}$ decreased significantly in both types of grain pattern (Table 4). This is reflected in the fact that the largest differential redness value $\left(\Delta a^{*}\right)$ was observed at those steaming times in the two types of grain pattern (Figs. 5(c) and $5(\mathrm{~d}))$. Steam-drying results vary between flat and quarter patterns when the wood has $50 \%$ moisture content. For flat grain boards, the redness value increases statistically with any steaming-drying time, while in quarter pattern boards, this color parameter was not statistically affected (Table 4). Again, this behavior may refer to the changes in the differential redness values $\left(\Delta a^{*}\right)$, which were positive (above one) for flat pattern boards at all steaming times (Fig. 5(c)). In the quarter pattern boards, the same values were negative, without exceeding 0.5 (Fig. $5(\mathrm{~d})$ ).

The color parameter $b^{*}$ decreased statistically after steaming-drying for both grain patterns in green condition, but for the wood with $50 \% \mathrm{MC}$, it was only affected statistically in the flat pattern boards that have been subjected to the steam-drying treatment during 3 and $9 \mathrm{~h}$ of streaming and in 


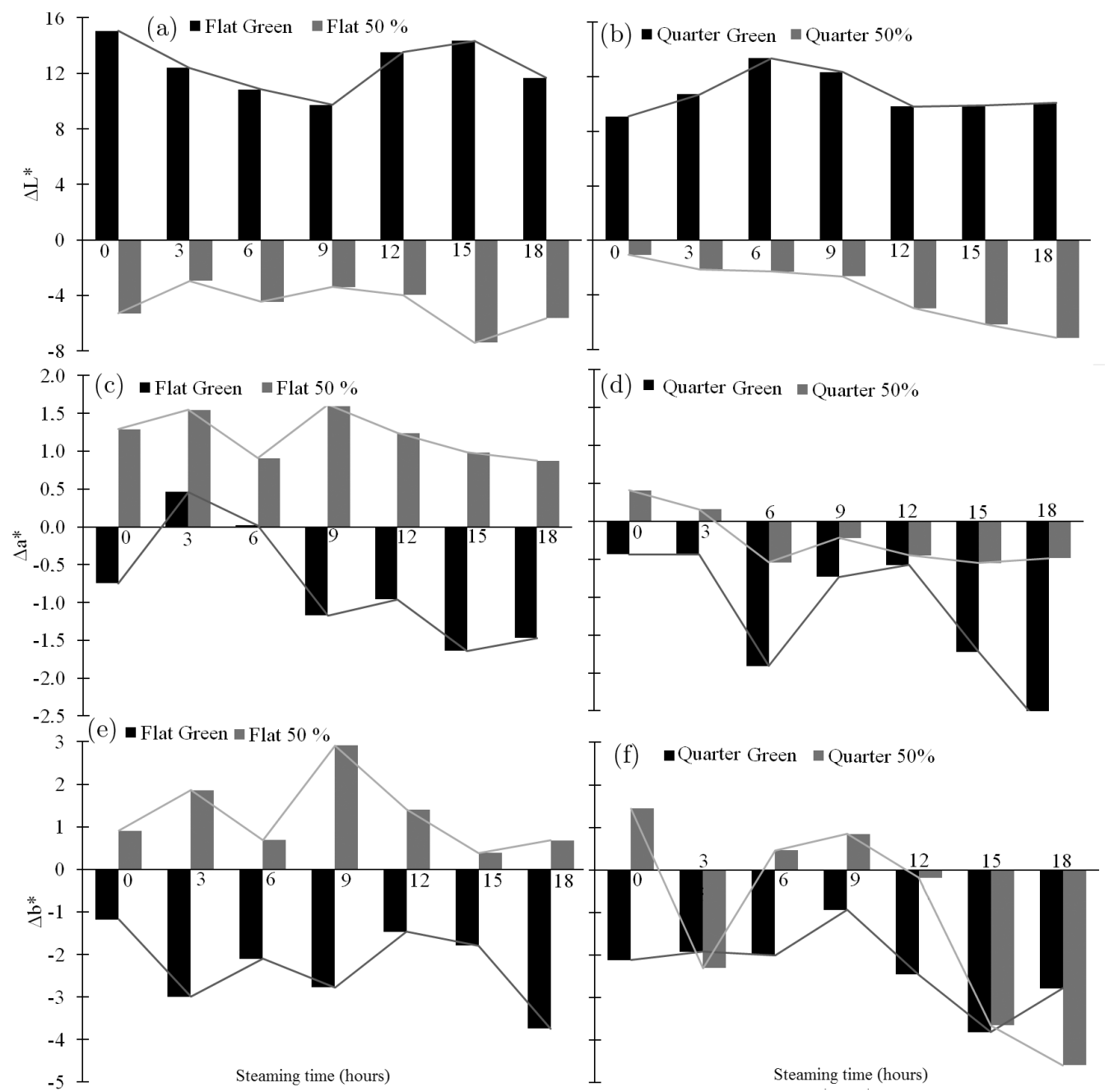

Fig. 5. Color differentials of parameters $L^{*}, a^{*}$ and $b^{*}$ before and after steam-drying Tectona grandis flat and quarter pattern boards in two moisture conditions (green and $50 \% \mathrm{MC}$ ).

quarter pattern boards between $15 \mathrm{~h}$ and $18 \mathrm{~h}$ of steaming (Table 4). The differential change of yellowness $\left(\Delta b^{*}\right)$ showed that the greatest differentials are observed at 3 and $9 \mathrm{~h}$ in flat pattern board, and after $15 \mathrm{~h}$ of steaming in quarter pattern boards (Figs. 5(e) and 5(f)).

The behavior of the color parameters is compared to other studies, such as Salas and Moya ${ }^{11}$ and Basri et al.,${ }^{31}$ which were conducted under similar moisture or grain pattern conditions. The above mentioned authors found that $L^{*}$ and $b^{*}$ diminished statistically when the wood is dried, whereas $a^{*}$ was statistically unaffected. The results were only congruent for $50 \% \mathrm{MC}$ wood and not for flat pattern (Table 4) or green-condition wood.

In the evaluation of the surface color change $\left(\Delta E^{*}\right)$ after the steam-drying treatment, compared to the teak from natural forest, a minor change was obtained in the flat grain wood between $3 \mathrm{~h}$ and $6 \mathrm{~h}$ steaming-drying, for both moisture conditions. Furthermore, color change tends to decrease in quarter pattern boards with increasing steaming-drying time (Fig. 6).

The wood color difference index $\Delta E^{*}$ (Eq. (1)) is expressed as a distance between two points in the color coordinate system, with the quadratic addition of each coordinate difference. ${ }^{20}$ Cui et al. ${ }^{32}$ mentioned that the color's change value $\left(\Delta E^{*}\right)$ defined the levels at which color differences are perceived. When the values of $\Delta E^{*}$ rise above 10 , color change is very appreciable. Consequently, it is preferable to find a steaming condition with the lowest $\Delta E^{*}$ values relative to teak wood from natural forests ${ }^{5}$ in order to 


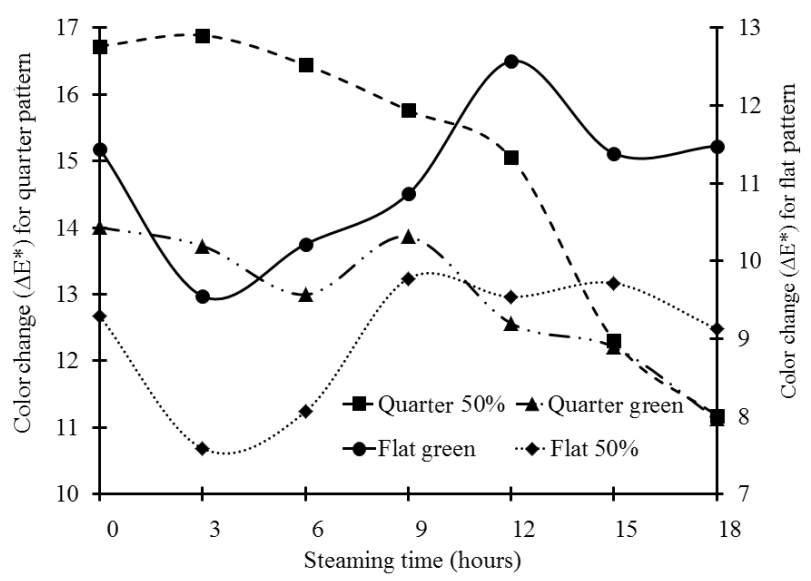

Fig. 6. Color change $\left(\Delta E^{*}\right)$ of Tectona grandiswood surface of flat and quarter pattern boards, in green condition and $50 \% \mathrm{MC}$ after different steaming-drying times.

achieve the desirable color. According to the $\Delta E^{*}$ values found with the different steaming times and grain patterns (Fig. 6), the lowest color difference between steamed wood and model teak is achieved after $3 \mathrm{~h}$ of the steam-drying of the flat pattern boards at $50 \%$ moisture content and $6 \mathrm{~h}$ of steam-drying of the green condition wood. Meanwhile, for quarter pattern boards, the best condition is $18 \mathrm{~h}$ of the steam-drying (Fig. 5).

Color changes relative to changes in the modifications of the chemical composition of the surface of flat pattern boards, coincide with the diminution of the relative intensity between 1596 and $1733 \mathrm{~cm}^{-1}$ (Figs. 3(h) - 3(l)) and the lowest value of the wood color difference index $\Delta E^{*}$ in this type of grain pattern (Fig. 6). As for the quarter pattern board, with the constant change of the ratio of intensity (ratio $\left.I_{n} / I_{1031}\right)$, it also coincides with the decrease of the color change with the steaming time (Fig. 6). This means that color changes of the wood probably occur due to the loss of the $\mathrm{C}=\mathrm{O}$ group linked to the aromatic skeleton of lignin. Specifically, cross-links have been formed between aromatic units in the lignin. However, hemicellulose degradation may also be occurring. Glucose, for example, showed alteration in the signals at $1318 \mathrm{~cm}^{-1}$ (Fig. 3(c)) or xylan, indicated by the alteration in the bands at $1453 \mathrm{~cm}^{-1}$ (Fig. 3(d)), which favor dissolution of carbohydrates during steaming, ${ }^{31}$ leaving it more exposed to lignin. As a result, redness $\left(a^{*}\right)$ in the wood tends to be higher in the case of flat green wood after $3 \mathrm{~h}$ of steaming (Fig. 3(c)), and the differences in the values of $\Delta a^{*}$ in quarter pattern boards after $18 \mathrm{~h}$ of steaming are greater.

\section{Conclusion}

The FTIR bands at 1031, 1053, 1108, 1158, 1231, 1318, 1373, 1419, 1453, 1506, 1558, 1595, 1652, 1717 and $1733 \mathrm{~cm}^{-1}$ signals in the range studied $\left(800-1800 \mathrm{~cm}^{-1}\right)$ were found to be present in the surfaces of all the different treatments. On the other hand, the chemical components with signals at 1540, $1554,1575,1616,1635,1675$ and $1695 \mathrm{~cm}^{-1}$ were evidenced in the FTIR spectra of the quarter pattern samples of wood not subjected to steaming, therefore, were only present in wood before steaming. Regarding the signals at $1158,1231,1373$ and $1419 \mathrm{~cm}^{-1}$, it was not possible to observe any trend in this intensity; however, bands at 1053, 1108, 1453, 1506, 1536, 1558, $1595,1652,1683,1700$ and $1733 \mathrm{~cm}^{-1}$ showed a decrease in the vibration ratio with the steaming time. The only signal where this ratio augmented was at $1318 \mathrm{~cm}^{-1}$ probably due to the reduction of the cellulose crystallinity by the steaming-drying process, however further research is required to confirm it.

Different steaming-drying times changed the magnitude of the color parameters, $L^{*}$ in particular, followed by yellowness $\left(b^{*}\right)$ and then by redness $\left(a^{*}\right)$. The evaluation of the color change of the surface due to steaming-drying, with teak wood from natural forests as the model, shows that flat pattern boards present the lowest change between $3 \mathrm{~h}$ and $6 \mathrm{~h}$ of steamingdrying in the two moisture conditions, while in quarter pattern boards, color change tends to diminish with the increase of the steaming-drying time.

Color changes relative to changes in the modifications of the chemical composition of the surface of flat pattern boards, coincide with the diminution of the relative intensity between $1596 \mathrm{~cm}^{-1}$ and $1733 \mathrm{~cm}^{-1}$ (Fig. 1) and the lowest value of the wood color difference index $\Delta E^{*}$ in this type of grain pattern (Fig. 5). As for the quarter pattern boards, the constant change of the ratio of intensity (ratio $\left.I_{n} / I_{1031}\right)$ also coincides with the decrease of the color change with the steaming time. This means that color changes of the wood probably occur due to the loss of the $\mathrm{C}=\mathrm{O}$ group linked to the aromatic skeleton of lignin. 


\section{Acknowledgments}

The authors wish to thank the Vicerrectoria de Investigación y Extensión at the Instituto Tecnológico de Costa Rica (ITCR), and we thank Life Forestry Costa Rica S.A. for providing a sample of their 11year-old teak trees from their plantations for the present study.

\section{References}

1. FAO, Planted Forests and Trees, Global Planted Forests Thematic Study: Results and analysis, Working Paper No. 38, FAO, Rome (2006).

2. R. Moya, B. Bond and H. Quesada, Wood Sci. Technol. 48 (2014) 411.

3. R. Moya and J. Calvo, Ann. For. Sci. 69 (2012) 947.

4. P. K. Thulasidas, K. M. Bhat and T. Okuma, J. Trop. For. Sci. 18 (2006) 51.

5. R. Moya and B. Marin, New Forests 42 (2011) 3296.

6. K. M. Bhat, Wood News 9 (1999) 48.

7. R. Moya and A. Berrocal, Ann. For. Sci. 67 (2010) 107.

8. S. Fehér, S. Komán, Z. Börcsök and R. Taschner, BioResources 9 (2014) 3456.

9. Y. Cao, J. Jiang, J. Lu, R. Huang, J. Jiang and Y. Wu, BioResources 7 (2012) 2809.

10. A. Berrocal and P. Agüero, Kurú Rev. For. 7 (2006) 1.

11. C. Salas and R. Moya, Drying Technol. 32 (2014) 301.

12. J. Guo, K. Song, L. Salmén, Y. Yin, Carbohydrate Polym. 115 (2015) 207.

13. X. N. Huang, D. Kocaefe, Y. Kocaefe, Y. Boluk and C. Krause, Appl. Surf. Sci. 264 (2013) 117.

14. F. Lionetto, R. Sole, D. Cannoletta, G. Vasapollo and A. Maffezzoli, Materials 5 (2012) 1910.

15. J. S. Stevanic and L. Salmén, Holzforschung 63 (2009) 497.

16. D. Varga and M. E. Van der Zee, Holz Roh. Werk. 66 (2008) 11.
17. L. Calienno, C. Pelosi, R. Picchio, G. Agresti, U. Santamaria, F. Balletti and A. L. Monaco, Stud. in Conserv. 60 (2015) 131.

18. M. Y. Li, S. C. Cheng, D. Li, S. N. Wang, A. M. Huang and S. Q. Sun, Chin. Chem. Lett. 26 (2015) 221.

19. R. S. Hunter and R. W. Harold, HunterLab: The Measurement of Appearence (John Wiely and Sons, New York, 1995).

20. American Society for Testing and Materials (ASTM), ASTM D2244-11: Standard Practice for calculation of Color Toleraces and Color differences from instrumentally measured color coordinates, ASTM, West Conshohocken, PA (2014).

21. A. K. Moore and N. L. Owen, Appl. Spectrosc. Rev. 36 (2001) 65.

22. N. H. Okoye, A. N. Eboatu, J. S. Fabiyi, P. I. Udeozo, R. U. Arinzea and S. C. Odinma, Am.-Eurasian J. Sci. Res. 9 (2014) 45.

23. G. Bonifazi, L. Calienno, G. Capobianco, A. Lo Monaco, C. Pelosi, R. Picchio and S. Serranti, Polym. Degrad. Stab. 113 (2015) 10.

24. M. Åkerholm and L. Salmén, Polymer 42 (2001) 963.

25. L. P. Ramos, Quím Nova 26 (2003) 863.

26. G. Garrote, H. Domínguez and J. C. Parajó, Holz Roh. Werk. 59 (2001) 53.

27. B. Dos Santos, V. Sâmia, G. I. Bolzon and J. L. Monteiro de Matos, Cerne 20 (2014) 337.

28. M. Nakamura, Y. Miyake and T. Nakano, J. Wood Sci. 58 (2012) 505 .

29. N. Gierlinger, D. Jacques, M. Grabner, R. Wimmer, M. Schwanninger, P. Rozenberg and L. E. Pâques, Trees 18 (2004) 102.

30. J. C. Valverde and R. Moya, Color Res. Appl. 39 (2014) 519.

31. E. Basri, D. Rohadi, T. Priadi and I. Wahyudi, J. Ilmu Tek. Kayu Tropis 2 (2004) 57.

32. W. Cui, P. Kamdem and T. Rypstra, Wood Fiber Sci. 36 (2004) 291. 